\title{
KONTRIBUSI KOMPETENSI PEDAGOGIK, IKLIM KERJA, DAN ETOS KERJA TERHADAP KINERJA GURU OLAHRAGA SMA DI KABUPATEN BADUNG
}

\author{
Oleh \\ I.K. Sujana, Nyoman Dantes, Nyoman Natajaya
Program Studi Administrasi Pendidikan, Program Pascasarjana Universitas Pendidikan Ganesha
Singaraja. Indonesia \\ e-mail: \{ketut.sujana,nyoman.dantes,nyoman.natajaya\}@pasca.undiksha.ac.id
}

\begin{abstract}
ABSTRAK
Penelitian ini bertujuan untuk mengetahui kontribusi kompetensi pedagogik, iklim kerja, dan etos kerja terhadap kinerja guru olahraga SMAdi kabupaten badung. Penelitian ini tergolong ex-post facto. Populasi penelitian ini berjumlah 35 orang dan keseluruhan menjadi sampel penelitian karena jumlah populasi di bawah 100. Data kompetensi pedagogik, iklim kerja, etos kerja dan kinerja guru-guru olah raga SMA dikumpulkan dengan kuesioner model skala likert. Data yang diperoleh dianalisis secara statistik dengan analisis regresi sederhana, analisis regresi ganda 3 prediktor dan sumbangan efektif. Temuan penelitian ini adalah; (1) terdapat kontribusi yang signifikan kompetensi pedagogik terhadap kinerja guru melalui persamaan garis regresi $\hat{\mathrm{Y}}=65,795+0,540 \mathrm{X}_{1}$ dengan kontribusi sebesar $29,6 \%$ dan sumbangan efektif sebesar 10,1\%., (2) terdapat kontribusiyang signifikan iklim kerja terhadap kinerja guru melalui persamaan garis regresi: $\hat{\mathrm{Y}}=50,089+0,737 \mathrm{X}_{2}$ dengan kontribusi sebesar $37,2 \%$ dan sumbangan efektif sebesar $16,5 \%$, (3) terdapat kontribusiyang signifikan etos kerja guru terhadap kinerja guru melalui persamaan garis regresi $\hat{\mathrm{Y}}=55,531$ $+0,653 X_{3}$ dengan kontribusi sebesar $38,8 \%$ atau sumbangan efektif sebesar $15,9 \%$, dan (4) secara bersama-sama terdapat kontribusi yang signifikan kompetensi pedagogik, iklim kerja, dan etos kerja terhadap kinerja guru-guru olah raga SMA se-Kabupaten Badung melalui persamaan garis regresi $\hat{Y}=26,844+0,208 X_{1}+0,370 X_{2}+0,302 X_{3}$ dengan kontribusi sebesar $42,5 \%$. Dengan demikian maka ke tiga variabel tersebut dapat dijadikan predictor tingkat kecendrungan kinerja guru olah raga SMA se-Kabupaten Badung.
\end{abstract}

Kata Kunci : kompetensi pedagogik, iklim kerja, etos kerja,kinerja guru-guru olah raga

\section{ABSTRACT}

This study aims at discovering the contribution of pedagogical competency, working climate, and working ethos on performance of senior high school tecahers' sport in badung regency. This research is ex-post facto. The population of this research is 35 sport teachers and all of them were selected to be the sample because the number was lower than 100 . The data of pedagogical competency, working climate, working ethos and teacher's performance were collected by using questionnaire with Likert scale. The collected data were analyzed by using simple regression, multiple regression with three predictors and effective contribution. This research discovers: (1) there is a significant contribution of pedagogical competency on sport teacher's performance with regression line equation of $\hat{Y}=65,795+$ $0,540 X_{1}$ with contribution of $29.6 \%$ and effective contribution of $10.1 \%$, (2) there is a significant contribution of working climate on sport teacher's performance with regression line 
equation of $\hat{\mathrm{Y}}=50,089+0,737 \mathrm{X}_{2}$ with contribution of $37.2 \%$ and effective contribution of $16.5 \%$, (3) there is a significant contribution of pedagogical competency on sport teacher's performance with regression line equation of $\hat{\mathrm{Y}}=55,531+0,653 \mathrm{X}_{3}$ with contribution of $38.8 \%$ and effective contribution of $15,9 \%$, and (4) simultanously, there is a significant contribution of pedagogical competency, working climate, and working ethos on sport

teacher's performance with regression line equation of $\hat{Y}=26,844+0,208 X_{1}+0,370 X_{2}+$ $0,302 X_{3}$ with contribution of $42.5 \%$. it can be concluded that all the independent variables can be used as prdictors of the performance of senior high school tecahers' sport in Badung regency.

Keywords: pedagogical competency, working climate, working ethos, teachers' performance

\section{PENDAHULUAN}

Pendidikan merupakan faktor utama dalam pembentukkan pribadi manusia. Pendidikan sangat berperan dalam membentuk baik atau buruknya pribadi manusia menurut ukuran normatif. Menyadari akan hal tersebut, pemerintah sangat serius menangani bidang pendidikan, sebab dengan sistem pendidikan yang baik diharapkan muncul generasi penerus bangsa yang berkualitas dan mampu menyesuaikan diri untuk hidup bermasyarakat, berbangsa dan bernegara. Reformasi pendidikan merupakan respon terhadap perkembangan tuntutan global sebagai salah satu upaya untuk mengadaptasikan sistem pendidikan dalam upaya mengembangkan sumber daya manusia untuk memenuhi tuntutan zaman seiring perkembangan Ilmu Pengetahuan dan Teknologi (Iptek).

Empat pilar pendidikan universal yang dirumuskan oleh UNESCO (1996) dalam Dantes (2007), yang perlu dikembangkan oleh lembaga pendidikan formal, yaitu: (1) learning to know (belajar untuk mengetahui), bahwa pembelajaran dilakukan agar siswa memperoleh pengetahuan, para pendidik perlu mengajarkan siswa untuk belajar bagaimana belajar. (2) learning to do (belajar untuk melakukan sesuatu), bahwa pembelajaran dilakukan agar siswa dapat mengembangkan diri, memotivasi diri untuk berbuat sesuatu yang baik dan produktif. Hal ini akan bisa terlaksana jika sekolah memfasilitasi siswa untuk mengaktualisasikan keterampilan yang dimilikinya, bakat dan minatnya. (3) learning to be (belajar untuk menjadi seseorang), bahwa pembelajaran dilakukan agar siswa memiliki jati diri berdasarkan nilai-nilai hidup, berbudipekerti, bisa bertanggungjawab pada diri sendiri, keluarga, bangsa dan negara. (4) learning to live together (belajar untuk menjalani kehidupan bersama), bahwa pembelajaran dilakukan agar siswa memiliki sikap, dan prilaku, yang mendasari kemampuan dan dorongan untuk dapat hidup bersama, agar setiap individu memahami pentingnya pemahaman terhadap orang lain, menerima setiap persamaan dan perbedaan, dan menyadari adanya saling ketergantungan dalam hidup bermasyarakat (Delors,dkk.1996, dalam Dantes, 2007).

Agar dapat melaksanakan keempat pilar pendidikan di atas, serta untuk mencapai tujuan pendidikan nasional tersebut maka dibutuhkan guru yang berkompeten.Kompetensi yang wajib dimiliki oleh guru telah dituangkan dalam Peraturan Pemerintah Republik Indonesia Nomor 74 tahun 2008 pasal 1 ayat 1 yang menyatakan bahwa, guru adalah pendidik profesional dengan tugas utama mendidik, mengajar, membimbing, mengarahkan, melatih, menilai, dan mengevaluasi peserta didik pada pendidikan anak usia dini jalur pendidikan formal, pendidikan dasar, dan pendidikan menengah. Pasal 3 ayat 2 menyatakan, Kompetensi Guru sebagaimana dimaksud meliputi kompetensi pedagogik, kompetensi kepribadian, kompetensi sosial, dan kompetensi profesional.

Kompetensi pedagogik sebagaimana dimaksud pada ayat (2) merupakan kemampuan Guru dalam pengelolaan pembelajaran peserta didik yang sekurang-kurangnya meliputi: (a) pemahaman wawasan atau landasan kependidikan; (b) pemahaman terhadap peserta didik; (c) pengembangan kurikulum atau silabus; (d) perancangan pembelajaran; (e) pelaksanaan pembelajaran yang mendidik dan dialogis; (f) pemanfaatan teknologi pembelajaran; ( $\mathrm{g}$ ) evaluasi hasil belajar; dan (h) pengembangan peserta didik untuk mengaktualisasikan berbagai potensi yang dimilikinya. 
Kinerja guru merupakan masalah yang sangat penting bagi setiap sekolah. Kinerja guru yang sangat tinggi sangat diperlukan dalam setiap usaha kerjasama guru untuk tujuan sekolah, seperti diketahui bahwa pencapaian tujuan organisasi adalah sesuatu yang sangat diidamidamkan oleh setiap sekolah. Guru yang mempunyai kinerja rendah akan sulit untuk mencapai hasil yang diharapkan. Masalah kinerja guru bukanlah timbul begitu saja atau timbul secara sembarangan. Kinerja guru dapat ditingkatkan diantaranya dengan memberikan motivasi yang sudah tentu dengan jalan menyampaikan informasi melalui komunikasi dari atasan kepada bawahannya.

Ukuran kinerja guru terlihat dari rasa tanggungjawabnya menjalankan amanah, profesi yang diembannya, rasa tanggungjawab moral dipundaknya. Semua itu akan terlihat kepada kepatuhan dan loyalitasnya di dalam menjalankan tugas keguruannya di dalam kelas dan tugas kependidikannya di luar kelas. Sikap ini akan dibarengi pula dengan rasa tanggungjawabnya dalam mempersiapkan segala perlengkapan pembelajaran sebelum melaksanakan proses pembelajaran. Selain itu, guru juga sudah mempertimbangkan akan metodologi yang akan digunakan, termasuk alat media pendidikan yang akan dipakai, serta alat penilaian apa yang digunakan di dalam pelaksanaan evaluasi.

Rendahnya kinerja dan prestasi guru merupakan salah satu faktor penyebab rendahnya mutu pendidikan di Indonesia (Sulistyorini,2001). Walaupun pandangan seperti ini tidak sepenuhnya benar, namun cukup beralasan, mengingat faktor guru memegang peranan paling penting dan paling sering berkomunikasi dengan siswa. Walaupun guru hanya merupakan salah satu faktor penyebab rendahnya mutu pendidikan, namun kontribusinya sangat besar terutama dalam meningkatkan prestasi belajar siswa. Hal ini didukung oleh hasil penelitian yang menunjukkan bahwa prestasi belajar siswa di sekolah dasar di Indonesia ditentukan oleh beberapa faktor, antara lain: kontribusi guru 34\%, sarana dan prasarana $26 \%$, pengelolaan (manajemen) $22 \%$, dan waktu belajar 18\% (wija, 1998).

Danim (2002) mengungkapkan bahwa salah satu ciri krisis pendidikan di Indonesia adalah guru belum mampu menunjukkan kinerja (work performance) yang memadai. Hal ini menunjukkan bahwa kinerja guru belum sepenuhnya ditopang oleh derajat penguasaan kompetensi yang memadai, oleh karena itu perlu adanya upaya yang komprehensif guna meningkatkan kompetensi guru. Lebih lanjut Suroso (2002), menyebutkan bahwa rendahnya kinerja guru disebabkan oleh berbagai faktor antara lain: (1) insentif/gaji secara nasional masih rendah; (2) gaya kepemimpinan kepala sekolah; (3) motivasi berprestasi guru; (4) kompetensi guru khususnya kompetensi pedagogik; (5) minimnya kesempatan yang diberikan kepada guru untuk mengikuti kegiatan pengembangan sumber daya dalam bentuk in-service training: (6) kurangnya kesempatan membaca karena persoalan mencari pekerjaan tambahan; (7) prosedur kenaikan pangkat yang sulit terutama ke golongan diatas IV/a, merupakan salah satu penyebab rendahnya motivasi berprestasi guru; (8) adanya perasaan tidak bangga menjadi guru karena perlakuan kurang adil terhadap guru, sehingga guru merasa enggan meningkatkan kompetensi pedagogiknya dan (9) rasa kurang aman dalam bertugas.

Berdasarkan uraian pada latar belakang, maka dapat dirumuskan beberapa permasalahan sebagai berikut.

1. Seberapa besar kontribusi kompetensi pedagogik guru terhadap kinerja guru olah raga SMA di Kabupaten Badung?

2. Seberapa besar kontribusi iklim kerja terhadap kinerja guru olah raga SMA di Kabupaten Badung?

3. Seberapa besar kontribusi etos kerja guru terhadap kinerja guru olah raga SMA di Kabupaten Badung?

4. Seberapa besar kontribusi secara bersama-sama kompetensi pedagogik guru, iklim kerja sekolah dan etos kerja guru terhadap kinerja guru olah raga SMA di Kabupaten Badung?

Rumusan masalah penelitian di atas secara umum tujuan penelitian adalah untuk mengetahui kontribusi kompetensi pedagogik guru, iklim kerja dan etos kerja guru terhadap kinerja guru olah raga di Kabupaten Badung. 


\section{METODE PENELITIAN}

Penelitian ini termasuk penelitian non-treatment atau ex-post facto karena tidak dilakukan perlakuan pada variabel dan hanya mengambil data secara langsung. Lebih lanjut, penelitian ini termasuk pendekatan kuantitatif dengan rancangan korelasional karena dalam penelitian ini mencoba mengetahui hubungan yang ada, antar variabel yang dikorelasikan (Koyan, 2012). Hasil penelitian hanyalah mendeskripsikan dan menganalisis hubungan antara kompetensi pedagogik, iklim kerja dan etos kerja dengan kinerja guru olah raga di Kabupaten Badung di Kabupaten Badung

Populasi dalam penelitian ini adalah seluruh guru-guru olah raga SMA se Kabupaten Badung tahun pelajaran 2015/2016 yang berjumlah 35 guru.

Untuk pengumpulan data tentang kompetensi pedagogik $\left(X_{1}\right)$, iklim kerja $(X 2)$, etos kerja $(\mathrm{X} 3)$ dan kinerja guru-guru olah raga se-Kabupaten Badung $(\mathrm{Y})$ digunakan kuesioner dengan pola skala likert. Sedangkan untuk memperoleh jumlah guru-guru yang ada di masingmasing sekolah digunakan metode dokumen, serta metode observasi digunakan sebagai metode pelengkap.

Dalam melakukan analisis data untuk penelitian ini ada tiga tahapan yang dilalui yakni : a. tahap deskripsi data, b. tahap pengujian persyaratan analisis, dan c. tahapan pengujian hipotesis.

\section{HASIL DAN PEMBAHASAN}

Hasil penelitian yang mencakup deskripsi tentang karakteristik masing-masing variabel penelitian, uraian tentang hasil pengujian persyaratan analisis, uji hipotesis, pembahasan dan implikasi penelitian. Hasil penelitian yang dimaksudkan adalah menyangkut deskripsi kompetensi pedagogik, deskripsi iklim kerja, deskripsi etos kerja dan deskripsi kinerja guru (Y) olahraga SMA se-Kabupaten Badung. Disamping itu, disajikan pula kontribusi kompetensi pedagogik terhadap kinerja guru, iklim kerja terhadap kinerja guru, etos kerja terhadap kinerja guru dan secara bersama-sama kompetensi pedagogik, iklim perja dan etos kerja terhadap kinerja guru-guru olah raga SMA se-Kabupaten Badung.

Untuk mendapatkan gambaran mengenai karakteristik distribusi skor dari masingmasing variabel, berikut disajikan skor tertinggi, skor terendah, harga rerata, simpangan baku, varians, median, modus, diagram batang, dan kategorisasi masing-masing variabel yang diteliti.

Hasil pengukuran kompetensi pedagogik terhadap 32 responden menunjukkan bahwa skor tertinggi yang dicapai responden adalah 168, sedangkan skor terendah yang dicapai responden adalah 100. Dan secara umum, rata-rata (mean) skor kompetensi pedagogik sebesar 138,81.

Diketahui bahwa sebagian besar data kompetensi pedagogik guru berada pada interval 136-147 dengan frekuensi 12. Selanjutnya, interval 124-135 dengan frekuensi 8 , interval 148159 dengan frekuensi 6 , interval 112-123 dengan frekuensi 3, interval 160-171 dengan frekuensi 2 dan interval 100-111 dengan frekuensi 1.

Dapat diamati kategori skor kompetensi pedagogik guru. Jika mengacu pada analisis deskriptif sebelumnya dimana nilai rata-rata adalah 138,81, maka kompetensi pedagogik guru olah raga SMA di Kabupaten Badung terkategori sedang. Secara spesifik, guru-guru yang menilai kompetensi pedagogiknye dengan kategori baik sebanyak 14 orang $(43,75 \%)$ dan kategori sedang sebanyak 18 orang $(56,25)$. Tidak ada guru yang menilai kompetensi pedagogiknya dalam kategori sangat tinggi, rendah dan sangat rendah. Jadi dapat disimpulkan bahwa sebagian besar guru-guru menilai kompetensi pedagogiknya tergolong sedang dengan frekuensi 18 dan rata-rata kompetensi pedagogik juga dalam kategori sedang.

Hasil pengukuran iklim kerja terhadap 32 guru menunjukkan skor tertinggi yang didapat adalah 149. Sedangkan skor terendah yang didapat adalah 99. Dan secara umum, rata-rata 
(mean) skor iklim kerja sebesar 123. Selanjutnya, skor yang diperoleh dikelompokan dengan aturan Sturges.

Dapat diketahui bahwa sebagain besar skor iklim kerja jatuh pada interval 117-125 dengan frekuensi 10. Selanjutnya adalah interval 126-134 dengan frekuensi 8. Berikutnya ada 3 interval yang sama dengan frekuensi 4, yaitu interval 99-107, 108-116 dan 135-143. Terakhir adalah interval 144-152 dengan frekuensi 2.

Dapat diketahui kategori iklim kerja. Jika mengacu pada nilai rata-rata iklim kerja sebesar 123, maka iklim kerja terkategori tinggi. Seacara spesifik, ada 24 guru (75\%) yang mengkategorikan iklim kerjanya tinggi, 6 guru (18,75\%) menilai iklim kerjanya sangat tinggi dan 2 guru $(6,25 \%)$ menilainya sedang. Sementara itu, tidak ada guru yang menilai iklim kerjanya rendah dan sangat rendah. Dengan demikian dapat disimpulkan bahwa iklim kerja sebagain besar terkategori tinggi dengan frekuensi 24 dan rata-rata guru oleh raga di Kabupaten Badung menilai iklim kerjanya terkategori tinggi.

Hasil pengukuran etos kerja terhadap 32 guru Olah raga menunjukkan skor tertinggi yang didapat adalah 150, sedangkan skor terendah yang didapat adalah 103 . Secara umum, nilai rata-rata (mean) etos kerja sebesar 130,5.

Diketahui bahwa sebagian besar etos kerja guru jatuh pada interval 143-150 dengan frekuensi 8. Selanjutnya adalah interval 127-134 dan 135-142 dengan frekuensi 6, interval 119126 dengan frekuensi 5, interval 103-110 dengan frekuensi 4 dan interval 111-118 dengan frekuensi 3.

Untuk mengetahui kecenderungan data etos kerja guru, penilaian acuan patokan (PAP) digunakan. Data variabel ini diukur dengan kuesioner dengan jumlah butir 30. Sehingga skor maksimum ideal yang didapat oleh responden adalah 150 dan skor minimum ideal adalah 30 .

Dapat diketahui kategori Etos kerja. Nilai rata-rata etos kerja adalah 130,5 yang berarti terkategori tinggi. Selanjutnya, dapat dijelaskan bahwa ada 14 guru $(43,8 \%)$ yang menilai etos kerjanya sangat tinggi, 17 guru $(53,1 \%)$ menilai etos kerjanya tinggi dan hanya ada 1 guru $(3,1 \%)$ yang menilai etos kerjanya sedang. Tidak ada guru yang menilai etos kerjanya rendah dan sangat rendah. Dengan demikian dapat disimpulkan bahwa sebagain besar para guru menilai etos kerjanya tinggi dengan frekuensi 17 dan rata-rata etos kerja guru olah raga di Kabupaten Badung terkategori tinggl.

Hasil pengukuran kinerja guru terhadap 32 guru penjas menunjukkan skor tertinggi yang didapat adalah 174. Sedangkan skor terendah yang didapat adalah 118 . Nilai rata-rata (mean) kinerja guru sebesar 140,75.

Dapat diketahui bahwa sebagain besar kinerja gur jatuh pada interval 138-147 dengan frekuensi 9. Selanjutnya dalah interval 128-137 dengan frekuensi 8 , interval 118-127 dengan frekuensi 7, interval 148-157 dengan frekuensi 4, interval 168-177 dengan frekuensi 3 dan interval 158-167 dengan interval 1.

Untuk mengetahui kecenderungan data kinerja guru, penilaian acuan patokan (PAP) digunakan. Data variabel ini diukur dengan kuesioner dengan jumlah butir 40 . Sehingga skor maksimum ideal yang didapat oleh responden adalah 200 dan skor minimum ideal adalah 40 .

Dapat diketahui kategori untuk kinerja guru. Dari nilai rata-rata yang didapat pada analisis deskriptif sebesar 140,75 maka dapat disimpulkan rata-rata kinerja guru terkategori tinggi. Secara lebih khusus, ada 20 guru (62,5\%) yang menilai kinerjanya dengan kategori sedang dan 12 guru (37,5\%) yang menilainya dengan kategori tinggi. Sementara tidak ada guru yang menilai kinerjanya dengan kategori sangat tinggi, rendah dan sangat rendah. 
Berdasarkan data ini maka dapat disimpulkan bahwa sebagain besar guru olah raga menilai kinerjanya terkategori sedang dengan frekuensi 20 , akan tetapi rata-rata kinerja guru terkategori tinggi.

Sebelum uji hipotesis dilakukan, terlebih dahulu dilakukan uji prasyarat yang lazim disebut uji asumsi klasik. Terdapat 5 uji prasyarat yang dilakukan, yaitu: uji normalitas sebaran data, uji linearitas dan keberartian arah regresi, uji multikolinearitas, uji heteroskedastisitas dan uji otokorelasi. Hasil uji prasyarat disajikan sebagai berikut.

Pengujian normalitas sebaran data dilakukan dengan menggunakan uji KolmogorovSmirnov (Liliefors Significance Correction) yang dikenakan terhadap skor kompetensi pedagogik, iklim kerja, etos kerja, dan kinerja guru. Dari hasil perhitungan dengan menggunakan program SPSS 13.0 for windows. nilai probalitas (Asymp. Sig. (2-tailed)) untuk semua variabel di atas 0,05 (Kompetensi pedagogik sebesar 0,815, iklim kerja sebesar 0,998, Etos kerja sebesar 0,910 dan kinerja guru sebesar 0,269). Ini berarti skor keempat variabel berdistribusi normal.

Uji linieritas garis regresi dimaksudkan untuk mengetahui keberartian koefisien arah regresi dari model linier antara variabel bebas dengan variabel terikat. Pengujian linieritas dilakukan dengan menggunakan uji F dengan bantuan program SPSS 13.0 for windows. Hasil analisis uji linieritas garis regresi pada table 4.11 di atas, menunjukkan bahwa untuk semua hubungan variabel, harga F Dev. from linierity diatas 0,05 . Dengan demikian dapat disimpulkan bahwa hubungan antara kompetensi pedagogik, iklim kerja, etos kerja dan kinerja guru-guru mempunyai hubungan yang linier. diketahui nilai probilitas linierity untuk semua pasangan variabel bebas dan terikat lebih kecil daripada 0,05. Hal ini berarti koefisien arah regresi berarti. Dengan kata lain, terdapat hubungan fungsional yang signifikan antara variabel bebas dan terikat.

Uji multikolinieritas dikenakan terhadap sesama variabel bebas yaitu skor Kompetensi pedagogik, Iklim kerja, Etos kerja dan Kinerja Guru. Untuk pengujian ini digunakan korelasi product moment antara sesama variabel bebas dengan memprediksi nilai VIF (variance inflation factor). Jika harga VIF $<10$ maka antara sesama variabel bebas tidak kolinier (Candiasa, 2010)..

Uji Teknik yang digunakan untuk mencari heteroskedastisitas adalah dengan menggunakan modul regression linier pada program SPSS 13.0 for windows. Kriteria keputusan adalah: (1) jika ada pola tertentu, seperti titik membentuk suatu pola tertentu yang teratur maka telah terjadi heteroskedastisitas, (2) jika tidak ada pola yang jelas, serta titik-titik menyebar secara acak hal ini berarti tidak terjadi heteroskedastisitas.

Uji autokorelasi menggunakan rumus Durbin-Watson. Perhitungan dilakukan dengan SPSS 16 for windows. Pada hasil penghitungan, didapat nilai $d=2,221$. Untuk responden 32 dan variabel bebas 3 , didapat nilai $D_{u}=1,650$ pada taraf kesalahan 0,05 . Berdasarkan kriteria yang ditentukan dimana nilai $D_{u}<d<4-D_{u}(1,650<2,221<2,35)$ maka data bebas dari gejala autokorelasi.

Setelah uji prasyarat terpenuhi maka akan dilanjutkan dengan uji hipotesis untuk menjawab permasalahan penelitian. Hipotesis yang diuji dalam penelitian ini adalah: (1) terdapat kontribusi yang signifikan kompetensi terhadap kinerja guru, (2) terdapat kontribusi yang signifikan iklim kerja terhadap kinerja guru, (3) terdapat kontribusi yang signifikan etos kerja terhadap kinerja guru, dan (4) secara bersama-sama, terdapat terdapat kontribusi yang signifikan antara kompetensi pedagogik, iklim kerja dan etos kerja terhadap kinerja guru.

Dalam ini disajikan hasil penelitian yang mencakup deskripsi tentang karakteristik masing-masing variabel penelitian, uraian tentang hasil pengujian persyaratan analisis, uji hipotesis, pembahasan dan implikasi penelitian. Hasil penelitian yang dimaksudkan adalah 
menyangkut deskripsi kompetensi pedagogik, deskripsi iklim kerja, deskripsi etos kerja dan deskripsi kinerja guru (Y) olahraga SMA se-Kabupaten Badung. Disamping itu, disajikan pula kontribusi kompetensi pedagogik terhadap kinerja guru, iklim kerja terhadap kinerja guru, etos kerja terhadap kinerja guru dan secara bersama-sama kompetensi pedagogik, iklim perja dan etos kerja terhadap kinerja guru-guru olah raga SMA se-Kabupaten Badung.

Hasil pengukuran kompetensi pedagogik terhadap 32 responden menunjukkan bahwa skor tertinggi yang dicapai responden adalah 168, sedangkan skor terendah yang dicapai responden adalah 100. Dan secara umum, rata-rata (mean) skor kompetensi pedagogik sebesar 138,81 Hasil pengukuran iklim kerja terhadap 32 guru menunjukkan skor tertinggi yang didapat adalah 149. Sedangkan skor terendah yang didapat adalah 99. Dan secara umum, rata-rata (mean) skor iklim kerja sebesar 123. Selanjutnya, skor yang diperoleh dikelompokan dengan aturan Sturges.

Hasil pengukuran etos kerja terhadap 32 guru Olah raga menunjukkan skor tertinggi yang didapat adalah 150, sedangkan skor terendah yang didapat adalah 103. Secara umum, nilai rata-rata (mean) etos kerja sebesar 130,5.

Hasil pengukuran kinerja guru terhadap 32 guru penjas menunjukkan skor tertinggi yang didapat adalah 174 . Sedangkan skor terendah yang didapat adalah 118 . Nilai rata-rata (mean) kinerja guru sebesar 140,75.

Hipotesis pertama menyatakan bahwa terdapat kontribusi yang signifikan kompetensi pedagogik terhadap kinerja guru Penjas. Untuk menguji hipotesis ini digunakan teknik regresi linier sederhana, korelasi, dan analisis kontribusi. Sesuai dengan Tabel 4.14 di atas diperoleh

persamaan garis regresi $\hat{Y}=65,795+0,540 X_{1}$ Hipotesis kedua menyatakan bahwa terdapat kontribusi yang signifikan Iklim kerja terhadap kinerja guru-guru olah raga. Untuk menguji hipotesis ini digunakan teknik regresi linier sederhana, korelasi, dan analisis kontribusi. Sesuai dengan Tabel 4.14 di atas diperoleh persamaan garis regresi $\hat{\mathrm{Y}}=50,089+0,737 \mathrm{X}_{2}$.

Hipotesis ketiga menyatakan bahwa terdapat kontribusi yang signifikan etos kerja terhadap kinerja guru-guru olah raga. Untuk menguji hipotesis ini juga digunakan teknik regresi linier sederhana, korelasi, dan analisis kontribusi.

Hipotesis keempat menyatakan bahwa secara bersama-sama, terdapat kontribusi yang signifikan kompetensi pedagogik, iklim kerja dan etos kerja terhadap kinerja guru olah raga. Untuk menguji hipotesis ini digunakan teknik regresi ganda. Hasil perhitungan regresi ganda diperoleh persamaan regresi $\hat{Y}=26,844+0,208 X_{1}+0,370 X_{2}+0,302 X_{3}$ dengan $F_{\text {reg }}=8,635$ dengan probabilitas (p) 0.000 (selengkapnya dapat dilihat pada lampiran). Karena nilai $p<0,000$ maka regresi dapat dipakai untuk memprediksi kompetensi pedagogi, iklim kerja dan etos kerja terhadap kinerja guru pada taraf kepercayaan 95\%.

Berdasarkan pengujian hipotesis diperoleh bahwa terdapat kontribusi yang signifikan kompetensi pedagogik terhadap kinerja guru-guru olah raga SMA se-Kabupaten Badung melalui persamaan garis regresi $\hat{Y}=65,795+0,540 X_{1}$ dengan $t_{\text {- }}$ iting $=3,548$ dengan nilai probabilitas ( $p) 0.001(p<0,05)$. Dalam penelitian ini ditemukan korelasi positif yang signifikan antara kompetensi pedagogik guru dengan kinerja guru-guru olah raga se-Kabupaten Badung sebesar 0,544 dengan besar kontribusi 29,6\%. Hal ini berarti makin tinggi kompetensi pedagogik guru, makin tinggi pula kinerja guru. Ini dapat dijadikan suatu indikasi bahwa kompetensi pedagogik dapat dipakai sebagai prediktor kinerja guru-guru olah raga SMA seKabupaten Badung atau dengan kata lain bahwa kompetensi pedagogik guru berfungsi determinan terhadap kinerja guru-guru olah raga SMA se-Kabupaten Badung. Sumbangan efektif (SE) variabel kompetensi pedagogik terhadap kinerja guru-guru olah raga SMA seKabupaten Badung sebesar 10,1\%.

Berdasarkan temuan dan pembahasan diatas, maka dapat disimpulkan empat implikasi penelitian ini, yaitu: karena terdapat kontribusi yang signifikan kompetensi pedagogik terhadap kinerja guru maka seorang guru harus mampu meningkatkan kompetensi pedagogiknya. Mengajar adalah tugas utama seorang guru. Untuk itu mengajar hendaknya efektif dan inovatif 
sesuai dengan perubahan jaman. Metode-metode pembelajaran yang masih berpusat pada guru hendaknya sudah dikurangi atau ditinggalkan menuju metode-metode yang lebih berspusat pada siswa.

Karena terdapat kontribusi yang signifikan iklim kerja terhadap kinerja guru maka iklim kerja harus ditingkatkan. Iklim kerja yang kondusif baik fisik maupun non fisik menambah semangat kerja guru. Semangat inilah yang memacu guru untuk bisa menunjukan kinerjanya dengan baik.

Karena terdapat kontribusi yang signifikan etos kerja guru terhadap kinerja guru maka guru harus meningkatkan etos kerja dalam melaksanakan semua kewajibannya sebagai guru.

Secara simultan para guru harus berusaha meningkatkan kompetensi pedagogik, iklim kerja dan etos kerja agar bisa menghasilkan kinerja yang maksimal. Selain guru, peningkatan iklim kerja juga harus dilakukan oleh kepala sekolah. Sebagai pemimpin tertinggi di sekolah, kepala sekolah harus mampu memfasilitasi terjadinya iklim kerja yang kondusif di sekolah.

\section{IMPLIKASI PENELITIAN}

Berdasarkan temuan dan pembahasan maka dapat disimpulkan empat implikasi penelitian ini, yaitu:

1. Karena terdapat kontribusi yang signifikan kompetensi pedagogik terhadap kinerja guru maka seorang guru harus mampu meningkatkan kompetensi pedagogiknya. Mengajar adalah tugas utama seorang guru. Untuk itu mengajar hendaknya efektif dan inovatif sesuai dengan perubahan jaman. Metode-metode pembelajaran yang masih berpusat pada guru hendaknya sudah dikurangi atau ditinggalkan menuju metode-metode yang lebih berspusat pada siswa.

2. Karena terdapat kontribusi yang signifikan iklim kerja terhadap kinerja guru maka iklim kerja harus ditingkatkan. Iklim kerja yang kondusif baik fisik maupun non fisik menambah semangat kerja guru. Semangat inilah yang memacu guru untuk bisa menunjukan kinerjanya dengan baik.

3. Karena terdapat kontribusi yang signifikan etos kerja guru terhadap kinerja guru maka guru harus meningkatkan etos kerja dalam melaksanakan semua kewajibannya sebagai guru.

4. Secara simultan para guru harus berusaha meningkatkan kompetensi pedagogik, iklim kerja dan etos kerja agar bisa menghasilkan kinerja yang maksimal. Selain guru, peningkatan iklim kerja juga harus dilakukan oleh kepala sekolah. Sebagai pemimpin tertinggi di sekolah, kepala sekolah harus mampu memfasilitasi terjadinya iklim kerja yang kondusif di sekolah.

\section{PENUTUP}

Guru merupakan salah satu komponen sekolah yang memegang peranan penting dalam menentukan mutu pendidikan di sekolah. Oleh karena itu guru dituntut untuk bekerja secara profesional sesuai dengan kemampuan yang dimilikinya. Kompetensi pedagogik merupakan kemampuan dasar seorang guru dalam melaksanakan tugas keguruannya dengan kemampuan tinggi, baik sebagai pengajar, pembimbing, maupun administator yang dilaksanakan secara bertanggung jawab dan layak.

Kompetensi pedagogik sebagaimana dimaksud pada ayat (2) merupakan kemampuan Guru dalam pengelolaan pembelajaran peserta didik yang sekurang-kurangnya meliputi: (a) pemahaman wawasan atau landasan kependidikan; (b) pemahaman terhadap peserta didik; (c) pengembangan kurikulum atau silabus; (d) perancangan pembelajaran; (e) pelaksanaan pembelajaran yang mendidik dan dialogis; (f) pemanfaatan teknologi pembelajaran; (g) evaluasi hasil belajar; dan $(\mathrm{h})$ pengembangan peserta didik untuk mengaktualisasikan berbagai potensi yang dimilikinya.

Selain kompetensi pedagogik guru, iklim kerja sekolah juga sangat penting . Mengingat iklim kerja juga berpengaruh terhadap kinerja guru. Iklim kerja (work climate) adalah suasana kerja ditempat mereka bekerja ditandai dengan adanya rasa aman, tenang, tentram, terjadi interaksi yang baik antara personil, adanya keterbukaan, terciptanya suasana keterbukaan, 
rasa tanggung jawab dan etos kerja. Hoy dan Miskel (1987) mengemukakan tiga unsur pokok yang mempengaruhi tingkah laku sosial yaitu: (1) lembaga atau institusi, (2) kelompok, (3) dan unsur individu. Ketiga unsur tersebut akan mempengaruhi kompetensi guru dalam proses pendidikan yang pada akhirnya akan meningkatkan hasil belajar yaitu meningkatnya prestasi belajar siswa. Iklim kerja yang baik pada suatu sekolah akan membuat para guru nyaman dalam bekerja. Kenyamanan inilah yang tentunya akan membuat guru senang dan tenang dalam bekerja sehingga guru mampu menunjukan kinerja yang maksimal.

Namun dalam kenyataannya, masih ditemui beberapa masalah tentang ketiga variabel tersebut. Berdasarkan apa yang telah diuraikan pada latar belakang masalah di atas, maka dapat diidentifikasi beberapa permasalahan yang ada di SMAN 1 Mengwi, sebagai berikut.

Melalui penelitian ini akan dilakukan analisis kontribusi secara bersama-sama dan terpisah ketiga variabel tersebut terhadap kinerja guru. Dengan demikian akan diketahui variabel mana yang banyak berkontribusi terhadap kinerja guru.

Data yang diperoleh dari sampel kemuadian dianalisis secara statistik. Ada tiga tahap analisis data, yaitu: a) tahap deskripsi data, b) tahap pengujian prasyarat analisis, dan c) pengujian hipotesis dengan menggunakan analisis regresi sederhana dan analisis regresi berganda dengan tiga prediktor. Selanjutnya dilakukan analisis sumbangan efektif masingmasing variabel bebas terhadap variabel terikat.

Hasil penelitian ini menunjukan (1) terdapat kontribusi yang signifikan kompetensi pedagogik terhadap kinerja guru melalui persamaan garis regresi $\hat{\mathrm{Y}}=65,795+0,540 \mathrm{X}_{1}$ dengan kontribusi sebesar 29,6\% dan sumbangan efektif sebesar 10,1\%, (2) terdapat kontribusi yang signifikan iklim kerja terhadap kinerja guru melalui persamaan garis regresi: $\hat{Y}$ $=50,089+0,737 \mathrm{X}_{2}$ dengan kontribusi sebesar $37,2 \%$ dan sumbangan efektif sebesar $16,5 \%$, (c) terdapat kontribusi yang signifikan etos kerja guru terhadap kinerja guru melalui persamaan garis regresi $\hat{\mathrm{Y}}=55,531+0,653 \mathrm{X}_{3}$ dengan kontribusi sebesar $38,8 \%$ atau sumbangan efektif sebesar 15,9\%, dan (d) secara bersama-sama terdapat kontribusi yang signifikan kompetensi pedagogik, iklim kerja, dan etos kerja terhadap kinerja guru-guru olah raga SMA se-Kabupaten

Badung melalui persamaan garis regresi $\hat{Y}=26,844+0,208 X_{1}+0,370 X_{2}+0,302 X_{3}$ dengan kontribusi sebesar $42,5 \%$.

Ada beberapa hal yang dapat disimpulkan dalam penelitian ini, yakni

(1) Terdapat kontribusi yang signifikan kompetensi pedagogik terhadap kinerja guru melalui persamaan garis regresi $\hat{Y}=65,795+0,540 \mathrm{X}_{1}$ dengan kontribusi sebesar $29,6 \%$ dan sumbangan efektif sebesar $10,1 \%$.

(2) Terdapat kontribusi yang signifikan iklim kerja terhadap kinerja guru melalui persamaan garis regresi: $\hat{Y}=50,089+0,737 X_{2}$ dengan kontribusi sebesar $37,2 \%$ dan sumbangan efektif sebesar $16,5 \%$.

(3) Terdapat kontribusi yang signifikan etos kerja guru terhadap kinerja guru melalui persamaan garis regresi $\hat{Y}=55,531+0,653 X_{3}$ dengan kontribusi sebesar $38,8 \%$ atau sumbangan efektif sebesar $15,9 \%$.

(4) Secara bersama-sama terdapat kontribusi yang signifikan kompetensi pedagogik, iklim kerja, dan etos kerja terhadap kinerja guru-guru olah raga SMA se-Kabupaten Badung melalui persamaan garis regresi $\hat{Y}=26,844+0,208 X_{1}+0,370 X_{2}+0,302 X_{3}$ dengan kontribusi sebesar $42,5 \%$.

Berdasarkan temuan tersebut dapat disimpulkan bahwa secara terpisah maupun simultan, terdapat kontribusi yang signifikan kompetensi pedagogik, iklim kerja, dan etos kerja guru terhadap kinerja guru-guru olah raga SMA se-Kabupaten Badung. Dengan demikian ketiga faktor tersebut dapat dijadikan prediktor atau determinan tingkat kecenderungan kinerja guru-guru olah raga SMA se-Kabupaten Badung. 


\section{DAFTAR RUJUKAN}

Abdul, Wahab dan Umiarso. 2011. Kependidikan dan Kecerdasan Spiritual. Yogyakarta: ArRuzz.

Aca, I Wayan. 2013. Kontribusi Kompetensi Profesional, Supervisi Pendidikan, dan Iklim Kerja terhadap Kinerja Guru SMP Negeri 2 Amlapura. Thesis: Program Studi Administrasi Pendidikan, Program Pascasarjana, Universitas Pendidikan Ganesha.

Anoraga,Panji dan Sri Suryanti.1995.Psikologi Perusahaan.Jakarta:Rineka Cipta.

Anoraga, P. 1998. Psikologi Kerja. Jakarta: Rineka Cipta.

Aqib, Zainal. 2002. Profesionalisme Guru Dalam Pembelajaran. Surabaya: Insan Cendekia.

Damayanti. 2009. Pengaruh Motivasi Kerja Karyawan Terhadap Produktifitas Kerja Karyawan CV. Bening Natural Furniture Di Semarang. Skripsi. Semarang : Program Studi Magister Manajemen Universitas Diponegoro.

Danim, Sudarwan. 2002. Inovasi Pendidikan Dalam Upaya Peningkatan Profesionalisme Tenaga Kependidikan. Bandung: Pustaka Setia.

Danim, Sudarman 2004. Motivasi Kepemimpinan dan Efektivitas Kelompok. Penerbit Rineka Cipta.

Dantes, Nyoman. 2007. Seritifikasi Guru dalam Jabatan antara Tantangan dan Peluang. Program Pascasarjana, Universitas Pendidikan Ganesha, Singaraja. Diakses dari: https://nyomandantes.wordpress.com/2009/09/30/sertifikasi-guru-dalam-jabatanantaratantangan-dan-peluang/

Depdikbud. 1995. Petunjuk Teknis Ketentuan Pelaksanaan Jabatan Fungsional Guru dan Angka Kreditnya. Jakarta : Depdikbud.

Depdiknas. 2000. Panduan Manajemen Sekolah. Jakarta: Dirjen Dikdasmen.

Depdikbud. 2002. Manajemen Peningkatan Mutu Berbasis Sekolah (buku 1, 2, 3, 4). Jakarta : Depdiknas, Dirjen Dikdasmen.

Istijanto. 2005. Riset Sumber Daya Manusia. Jakarta: PT Gramedia Pustaka Umum.

Jalal, Fasli dan Dedi Supriadi. 2001.Reformasi Pendidikan Dalam Konteks Otonomi Daerah. Yogyakarta: Adicita Karya Nusa.

Jensen, H. Sinamo, 2002, Ethos 21. Ethos Profesional di Era Digital Global, Jakarta: Institut Dharma Mahardika.

Kardiman. 2003.Ekonomi. Jakarta: Yudhistira.

Kartono, Kartini. 2006. Pemimpin dan Kepemimpinan. Jakarta: PT. Raja Grafindo Persada.

Koyan, I Wayan. 2012. Buku Ajar 2012; Statistik Teknik Analisis Data Kuantitatif. Singaraja: Universitas Pendidikan Ganesha Press. 
Kusnan, Ahmad, 2004. Analisis Sikap Iklim Organisasi, Etos Kerja dan Disiplin Kerja dalam Menentukan Efektivitas Kinerja Organisasi di Garnisun Tetap III Surabaya. Tesis. Universitas Airlangga, Surabaya.

Mink. 1993. A Dale Timpe. 1999. Seri Manajemen Sumber Daya Manusia (Kinerja/Performance), Cetakan 4. Jakarta, PT Elek Media Komputindo.

Morgan, Gareth; Burrell, Gibson, 1979 Sociological Paradigms and Organizational Analysis, London, Exeter, New Hampshire, Heinemann.

Mulyasa. 2006. Kurikulum Berbasis Kompetensi. Edisi-10.Bandung : Remaja Rosdakarya.

Ndraha, Taliziduhu. 2005. Budaya Organisasi. Jakarta: Rineka Cipta.

Novliadi, Ferry. 2009. Hubungan Antara Organization-Based Self-Esteem Dengan Etos Kerja. Fakultas Psikologi, Universitas Sumatera Utara. USU e-Repository.

Owens, 1991. Organisational Behavior in education. Bonston: Allyn and Bacon.

Prawirosentono, Suyadi. 1992. Ilmu Manajemen Umum. Jakarta: Bumi Aksara

Republik Indonesia. 2005. Peraturan Pemerintah Republik Indonesia Nomor 19 tahun 2005 tentang Standar Nasional Pendidikan. Sekretariat Negara. Jakarta.

Republik Indonesia. 2005. Undang-undang Republik Indonesia nomor 14 tahun 2005 tentang Guru dan Dosen. Sekretariat Negara. Jakarta.

Republik Indonesia. 2008. Peraturan Pemerintah Republik Indonesia Nomor 74 tahun 2008 tentang Guru. Sekretariat Negara. Jakarta.

Robbins, StephenP. 1984. Perilaku Organisasi. Edisi Bahasa Indonesia. PT. Prentihalindo, Jakarta.

Robbins. S. P. 1996.Perilaku Organisasi, Jilid 2. Prehallindo: Jakarta.

Rosmiani. 1996. Etos Kerja Nelayan Muslim Di Desa Paluh Sebaji Deli serdang Sumatera utara; Hubungan Antara kualitas Keagamaan dengan Etos Kerja. Thesis, Kerja Sama Program Pasca Sarjana Institut Agama Islam Negeri Jakarta \& Pasca Sarjana UI Jakarta.

Safaria, Trianto. 2004. Kepemimpinan. Yogyakarta: Graha Ilmu.

Samani Muchlas. 2006. Mengenal Sertifikasi Guru di Indonesia. Surabaya: SIC dan Asosiasi Peneliti Pendidikan Indonesia.

Salirawati. 2009. Kiat-kiat menjadi guru Profesional. Makalah: disampaikan dalam Workshop Peningkatan Profesionalisme Guru SMA Negeri 1 Purbalingga, tanggal $20-21$ Desember 2009 di SMA N 1 Purbalingga.

Sedaramayanti. 2001. Sumber daya Manusia dan Produktivitas Kerja. Jakarta: Mandar Maju.

Sergiovanni, T.J. 1987. The Principalship: A Reflective Practice Perspective. Boston: Ally and Bacon. 
Sinamo, Jansen. 2005. Delapan Etos Kerja Professonal. Jakarta: Institut Mahardika.

Subamia, I Wayan. 2009. Kontribusi Faktor Kemampuan Manajerial Kepala Sekolah, Iklim Sekolah, dan Motivasi Berprestasi Terhadap Kinerja Guru: Studi Pada Para Guru SMA Negeri Unggulan di Kota Denpasar. Tesis: Program Pascasarjana, Universitas Pendidikan Ganesha.

Sukarman, Herry. 2007. Membangun Etos Kerja Dikalangan Pendidik dan Tenaga Kependidikan. Bandung P4TK IPA.

Sukmadinata, Nana Staodih. 2003. Landasan Psikologi Proses Pendidikan. Bandung: PT. Remaja Rosdakarya.

Sulistyorini, 2001. Hubungan antara Keterampilan Manajerial Kepala Sekolah dan Iklim Organisasi dengan Kinerja Guru. Ilmu Pendidikan: 28 (1) 62-70.

Supardi dan Anwar. 2004. Motivasi Kerja. Puri Arsita Anam. Yogyakarta.

Suparlan. 2008. Menjadi Guru Efektif. Jakarta: Hikayat Publishing.

Supriadi. 2011. Mengangkat Citra dan Martabat Guru. Yogyakarta: Adicita Karya Nusa.

Suroso. 2002. In Memorian Guru. Jendela. Yogyakarta.

Thoha, Miftah. 2012. Perilaku Organisasi Konsep Dasar dan Implikasinya. Jakarta: PT Raja Grafindo Persada. 